Can, E. ve Topçuoğlu Ünal, F. (2019). Öyküleyici metin türünde yazma becerisini geliştirmeye yönelik bir uygulama: Kurgu Merdiveni. Ana Dili Eğitimi Dergisi, 7(1), 190-204.

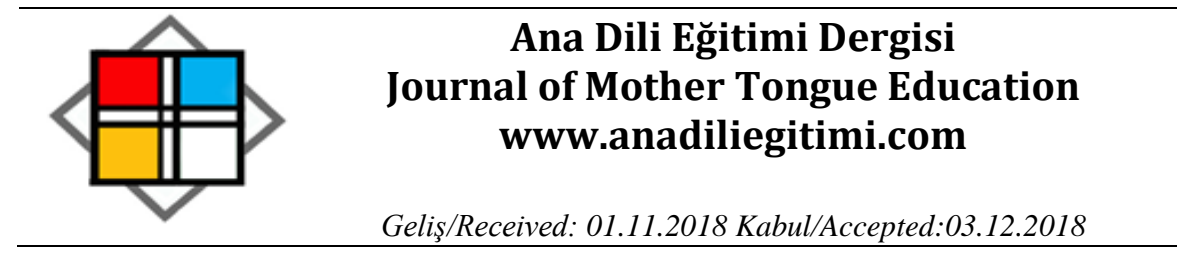

\title{
Öyküleyici Metin Türünde Yazma Becerisini Geliştirmeye Yönelik Bir Uygulama: Kurgu Merdiveni* $^{*}$
}

\author{
Emre CAN** \\ Fulya Topçuoğlu ÜNAL ${ }^{* * *}$
}

\begin{abstract}
Öz
Bu araştırmanın amacı öyküleyici metin türünde yazma becerisini geliştirmeye yönelik yeni bir uygulama geliştirmektir. Bu amaç doğrultusunda tasarlanmış olan Kurgu Merdiveni'nin, ortaokul öğrencilerinin yazma başarısına ve yazmaya yönelik tutumlarına etkisi incelenmiştir. Araştırmada nicel araştırma yöntemlerinden ön test son test kontrol gruplu deneysel model kullanılmıştır. Araştırma 2017-2018 eğitim öğretim yılında Bursa ilindeki bir ortaokulda öğrenim göre 7. sınıf öğrencileriyle yürütülmüştür. Araştırmanın uygulama süreci 10 hafta sürmüştür. Deney grubunda dersler Kurgu Merdiveni Tekniği kullanılarak işlenmiş, kontrol grubunda Türkçe Öğretim Programı'na göre derslere devam edilmiştir. Araştırmada veri toplama aracı olarak Öyküleyici Anlatım Değerlendirme Formu ve Ortaokul Öğrencilerine Yönelik Yazma Tutum Ölçeği kullanılmıştır. Araştırma sonucunda elde edilen bulgulara göre deney grubu lehine anlamlı bir farklılık tespit edilmiştir. Kurgu Merdiveni kullanılarak uygulanan yazma eğitimi, deney grubu öğrencilerinin yazma başarıları ve yazmaya yönelik tutumlarına olumlu etki etmiştir. Sonuç olarak bu araştırmayla Kurgu Merdiveni'nin yazma eğitiminde kullanılabilecek bir uygulama olduğu ortaya konmuştur.
\end{abstract}

Anahtar Kelimeler: Kurgu merdiveni, yazma, yazma becerisi, yazma eğitimi

\section{An Implementation for Improving Narrative Writing Skills: Fiction Stairs}

\begin{abstract}
The aim of this research is to develop a new practice for improving writing skill in a narrative text. The effect of Fiction Stairs which was designed for this aim, was investigated on writing success and on the writing attitudes of middle school students. The present research used pre-test posttest control group experimental design. Participants consisted of seven graders and were chosen from Bursa, Turkey in 2017-2018 school year. In the research, narrative expression evaluation form and writing attitude scale for middle school students were used as the data collection tools. According to the findings obtained from the research, the writing instruction which was performed by using Fiction Stairs had a positive effect on the attitudes of writing and writing success of the experiment group students.
\end{abstract}

Keywords: Fiction stairs, writing, writing education, writing skill

\footnotetext{
* Bu çalışma Doç. Dr. Fulya TOPÇUOĞLU ÜNAL danışmanlığında yapılan “Öyküleyici Metin Türünde Yazma Becerisini Geliştirmeye Yönelik Bir Uygulama: Kurgu Merdiveni” isimli yüksek lisans tezinin bir bölümünden oluşmaktadır.

** Öğretmen, Milli Eğitim Bakanlığı, Bursa, can4354@gmail.com, ORCID: 0000-0001-9112-3169

${ }^{* * *}$ Doç. Dr., Dumlupınar Üniversitesi, Eğitim Fakültesi, Türkçe Eğitimi Bölümü, Kütahya, fulya.topcuoglu.unal@dpu.edu.tr, ORCID: 0000-0003-3981-9841
} 


\section{Giriş}

Insan, sahip olduğu anlama ve anlatma yetisi sayesinde varlık âleminin en donanımlı canlısı olma özelliğine sahiptir. Bu donanımı sayesinde insan diğer canlılar karşısında üstün özelliklere sahip olur. İnsanın sahip olduğu bu özelliklerini kullanabilmesini sağlayan en temel araç dildir. Dil sayesinde insan, varlığını anlamlandırır ve bu anlamlandırma neticesinde sahip olduğu duygu, düşünce, hayal ve isteklerini çevresindekilere aktarır. Bu aktarımın yapılabilmesinde kullanılacak araçlardan biri de yazıdır.

Gelecek açısından insanoğlunun en büyük adımı yazıyı bulması olmuştur. Yazı sayesinde insan kalıcı olmayı başarabilmiş, ürettiği bilginin saklanmasını ve gelecek nesillere aktarılmasını yazı aracılığıyla gerçekleştirebilmiştir. Günümüzde birey okul döneminin başlamasıyla dâhil olduğu eğitim öğretim sürecinde edinmeye ve geliştirmeye başladığı yazma becerisi sayesinde yazıyı bir anlatma aracı olarak kullanmaya başlar.

Yazma, kişinin duygularını, düşüncelerini, hayal ettiklerini, tasarladıklarını, yaşadıklarını... kaleme alması, kâğıda aktarmasıdır (Göçer, 2016: 27). Karadağ ve Maden (2014: 266) 'e göre yazma, iletilmek istenen anlamların harf adı verilen sembollerle kodlanmasıdır. Bireyin kendini anlatma arzusunun neticesi olan yazma, aslında düşünülenlerin dışavurumudur. Karatay (2011)'a göre ise yazma duygu ve düşünceleri herhangi bir dilde kullanılan alfabedeki yazı karakterlerini, sembollerini, işaretlerini kullanarak başkalarına aktarma işidir.

Yukarıdaki tanımlarda da vurgulandığı üzere yazma, insanların duygu, düşünce, hayal ve isteklerini aktarmalarını sağlayan temel bir araçtır. Sosyal hayatın gereği olarak insan, mensubu olduğu toplumda yaşamını sürdürebilmesi için kendini sağlıklı olarak ifade edebilmelidir. Bu, insanın çevresiyle kuracağı iletişimin gereğidir. Temizkan’a (2010) göre insanın zihinsel ve psikolojik açıdan normal olarak algılanabilmesi çevresiyle düzenli iletişim kurabilmesine bağlıdır. İnsanın kendini ifade edebilmek için başvuracağı etkili yollardan biri de yazmadır. Bu açıdan yazma kişisel bir intiyaçtır.

Görüldüğü gibi yazma becerisi insanın sosyal ve psikolojik açıdan sağlıklı ve huzurlu bir hayat sürebilmesi için gereklidir. Bu beceriye sahip olmanın yanında bu becerinin geliştirilmesi son derece önemlidir. Ungan'a (2007) göre yazma becerisi gelişmiş olan bireylerin düşünceleri ile bilgileri arasında bağlantı kurma, bilgilerini transfer etme imkânları artmaktadır. Yazııı anlatım becerilerinin gelişmesiyle birlikte öğrencilerde yazılı anlatım konusunda estetik bir duyarlılık ön plana çıkmaktadır. Yazma becerisinin geliştirilmesi aynı zamanda birçok becerinin geliştirilmesine de katkı sağlamaktadır.

Yazı yazmak, aynı zamanda uygarlığın da önemli göstergelerindendir. Uygar bireyler ve uygar toplumlar, yazma ihtiyacı duyarlar. Yazılan ve gelecek kuşaklara aktarılan bilgiler sayesinde uygarlık ve insanlık yeni aşamalar kat eder. Bu açıdan bakıldığında yazmak, yaşamanın somutlaşmış biçimidir (Yaman, 2013: 83). 
Yazma becerisi, bireyin sosyal ve psikolojik gelişimini etkilemesi, kişilik gelişimine katkı sağlaması ve bireyler arası iletişimi sağlamadaki aracılığı ile sağlıklı toplumların oluşmasına katkısı bakımından geliştirilmesi gereken bir beceridir. Bu açıdan öğrencilere verilecek yazma eğitimi önem kazanmaktadır.

Yazma becerisinin geliştirilebilmesi için öncelikle öğrencilerde yazmaya yönelik istek uyandırılmalıdır. Öğrencilerin yazmaya istekli olması, yazmaya yönelik olumlu tutum geliştirebilmeleri uygulanacak olan yazma eğitimiyle yakından ilgilidir. Özellikle eğitim sürecinde öğretmenlerin öğrencilerde yazmaya karşı ilgi uyandıracak, yazmayı öğrencilere sevdirecek farklı yöntem, teknik ve uygulamaları kullanmaları gerekmektedir.

Ülkemizde öğretimin birinci basamağı olan ilkokulda yazmayı öğrenen birey, ortaokul sürecinde Türkçe dersleri aracılığıyla yazma alışkanlığını kazanmaya ve yazma becerisini geliştirmeye başlar. Eğitim sistemimizde yazma eğitimi, Türkçe eğitimi kapsamındadır. Yazma eğitiminin temel amacı öğrencilere kendilerini yazılı olarak ifade edebilme becerisini kazandırmak; bunu da dili doğru ve etkili bir şekilde kurallara uygun kullanarak yapabilmelerini öğretmektir. Bunun yanında öğrencilerin yazmayı alışkanlık haline getirmelerini ve bu becerilerini aktif olarak kullanmalarını sağlamak da yazma eğitiminin temel amaçları arasındadır.

Yazma eğitiminin etkili olabilmesi için öğrencilerin yazmaya yönelik geliştirecekleri tutum önemlidir. Yazma tutumu, yazma eyleminin, yazarın mutlu ya da mutsuz hislerini nasıl etkilediğini kapsayan bir eğilim olarak tanımlanır (Graham, Berninger ve Fan, 2007). Öğrencilerin yazmaya yönelik olumlu tutum geliştirebilmeleri konusunda öğretmene önemli görevler düşmektedir. Öğretmenlerin özellikle yazma yöntem ve tekniklerini iyi bilmeleri, yazma eğitiminde bu yöntem ve teknikleri amacına uygun olarak kullanabilmeleri gerekmektedir.

Yazma eğitiminde öğretmenlerin kullanacağı farklı yöntem teknik ve uygulamalar öğrencilerin yazmaya ilgi duymasını sağlayacağı gibi yazma becerisini edinmeleri ve geliştirmeleri konusunda katkı sağlayacaktır. Ayrıca öğretmenlerin yazma etkinliklerinde kullanacakları uygulamalar aracılığıyla öğrencilerin yazmaya yönelik olumsuz düşünce ve tutumlarını olumluya dönüştürmek mümkün olabilir. Bu bağlamda yazma eğitiminde kullanılabilecek, birçok becerinin kullanımını gerektiren yazma sürecini öğrenciler açısından kolaylaştıracak ve yazmayı öğrencilere sevdirecek yöntem, teknik ve uygulamalara ihtiyaç duyulmaktadır.

Bu araştırmada Kurgu Merdiveni'nin yazma başarısı ve yazmaya yönelik tutuma etkisi incelenerek yazma eğitiminde kullanılabilecek yeni bir uygulama geliştirilmeye çalışılmışır. Bu kapsamda yeni bir uygulama olarak geliştirilmesi amaçlanan Kurgu Merdiveni'nin ortaokul öğrencilerinin yazma başarısına ve yazmaya yönelik tutumlarına etkisi incelenmiştir. "Kurgu Merdiveni'nin ortaokul öğrencilerinin yazma başarısına ve yazmaya yönelik tutumlarına etkisi nedir?" 
sorusu araştırmanın problem cümlesini oluşturmaktadır. Bu amaç kapsamında şu alt problemlere cevap aranmıştır:

1. Kurgu Merdiveni uygulamasının ortaokul öğrencilerinin yazma başarısına etkisi nedir?

2. Kurgu Merdiveni uygulamasının ortaokul öğrencilerinin yazmaya yönelik tutumlarına etkisi nedir?

\section{Kurgu Merdiveni}

Kurgu Merdiveni, yapılandırmacı yaklaşıma göre yazma eğitiminde öyküleyici metin türünde kullanılabilecek bir uygulama olarak tasarlanmıştır. Yazmanın bir süreç dâhilinde planlanması gerektiğinden hareketle sürece dayalı yazma öğretimini dikkate almaktadır. Öğrencileri yazma öncesi, yazma sırası ve yazma sonrasında yapacakları konusunda yönlendirerek nitelikli ve anlamlı bir yazılı ürün ortaya koymalarına yardımcı olabilecek bir uygulamadır.

Kurgu Merdiveni;

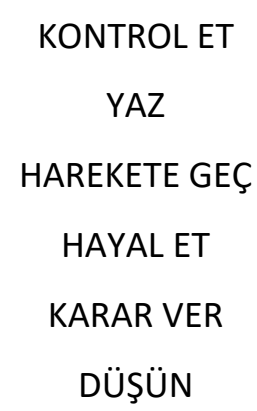

olmak üzere altı basamaktan oluşan bir uygulamadır. Her bir basamak kendi içerisinde farklı alt basamakları içermektedir. Yazma süreci dikkate alındığında DÜşÜN, KARAR VER, HAYAL ET ve HAREKETE GEÇ basamakları yazma öncesi; YAZ basamağı yazma sırası; KONRTOL ET basamağı yazma sonrası işlemleri kapsamaktadır.

Birinci Basamak: "Düşün"

"DÜşÜN" basamağı "Yazmaya başlamadan önce bilgi toplanır." ve "Metin türleri ve özellikleri hatırlanır." olmak üzere iki alt basamaktan meydana gelmektedir. Bu basamakta öğrencilerden yazma öncesinde yazacakları metin türü ve özellikleri hakkında araştırma yaparak bilgi toplamaları ve bu sayede yazacakları metni tür özelliklerine göre planlamaları beklenmektedir. Bu basamak aracılığıyla öğrenciler daha yazma sürecinin başında hangi türde metin yazdıklarının bilincinde olacaklar ve bu bilinçle yazma planlarını oluşturacaklardır.

ikinci Basamak: "Karar ver"

"KARAR VER" basamağı "Metin türüne karar verilir.", "Konu belirlenir.", "Olay örgüsü belirlenir.", "Şahıs ve varlık kadrosu oluşturulur.", "Yer (mekân) seçimi yapılır." ve "Zaman belirlenir." olmak üzere altı alt basamaktan meydana gelmektedir. Bu basamakta öğrencilerden öyküleyici anlatım biçimlerinden hangisini yazacağına karar verdikten sonra bir öyküleyici metinde bulunması gereken unsurları belirlemeleri beklenmektedir. Bir metinde bulunması gereken unsurlar, yazarın o 
metni yazarken kullanacağı malzemelerdir. Bu basamak aracığıyla öğrenciler yazma öncesinde, yazma sırasında kullanacakları malzemeleri hazırlamış olacaklardır.

Üçüncü Basamak: "Hayal et"

Öyküleyici metinler, olaya dayalı metinlerdir. Bu metinlerde olay ya da olaylar kurgu yoluyla anlatılmaktadır. Kurgu kısaca, yaşanmamış/gerçekleşmemiş bir olayı yaşanmış/gerçekleşmiş gibi anlatmak olarak ifade edilebilir. Yazarın kurgu yaparken kullanacağı en önemli becerisi hayal gücüdür.

"HAYAL ET" basamağı "Şahıs ve varlıkların fiziki ve psikolojik özellikleri düşünülür.", "Yer(mekân) tanımlanarak zihinsel tasviri yapılır.", "Zamanın özellikleri ve kahramanlar üzerindeki etkisi düşünülür." ve "Metinde yer verilecek olaylara kahramanların gözüyle bakılarak yazılacaklar zihinde tasarlanır." olmak üzere dört alt basamaktan meydana gelmektedir. Bu basamakta öğrencilerden yazacakları metni oluşturacak unsurlar konusunda ikinci basamakta belirledikleri unsurları hayal güçlerini kullanarak zenginleştirmeleri beklenmektedir. Bu basamak aracılığıyla öğrenciler düşünmeye ve hayal etmeye yönlendirilecek, öğrencilerin yazma becerilerinin yanında düşünme becerileri ve hayal güçleri de gelişecektir.

Dördüncü Basamak: "Harekete geç"

Yazma sürecinin sonunda anlam bütünlüğüne sahip bir metin ortaya çıkabilmesi ve metin aracılığıyla verilmek istenen mesaj açısından yazma sırasında kullanılacak sözcükler önemlidir. Konu bütünlüğünün de sağlanabilmesi açısından yazma sırasında kullanılacak sözcükler yazma öncesinde belirlenmelidir.

"HAREKETE GEÇ" basamağı "Metnin planı oluşturulur.", "Anahtar kelimeler belirlenir.", "Kelime havuzu oluşturulur." ve "Başlık belirlenir." olmak üzere dört alt basamaktan meydana gelmektedir. Bu basamak yazma işleminden önceki son basamaktır. Bu basamakta öğrencilerden yazacakları metne yönelik bir plan yapmaları, daha önceki basamaklarda belirledikleri unsurlardan hareketle anahtar sözcükler belirlemeleri ve sözcük havuzu oluşturmaları beklenmektedir.

Beşinci Basamak: "Yaz"

"YAZ" basamağı "Kâğıt ve sayfa düzenine dikkat edilir.", "HAYAL ET basamağında tasarlanalar genişletilerek yazıya dökülür.", "Söz sanatlarından yararlanılır. (Betimleme, Kişileştirme, Benzetme...)" ve "Imla ve noktalamaya dikkat edilir." olmak üzere dört alt basamaktan meydana gelmektedir. Bu basamak yazma işleminin gerçekleştirildiği basamaktır. Bu basamakta öğrencilerden önceki basamaklarda yaptıkları hazırlık çerçevesinde kurguladıklarını bir düzen içerisinde estetik olarak yazıya dökmesi beklenmektedir.

Altıncı Basamak: "Kontrol et"

"KONTROL ET" basamağı "Anlam bütünlüğü ve mantık akışı yönünden metin incelenir.", "Yazım kuralları ve noktalama bakımından metin incelenir." ve "Başlığın içeriğe uygunluğu incelenir." olmak üzere üç alt basamaktan meydana gelmektedir. Bu basamak değerlendirme basamağıdır. Bu 
basamakta öğrencilerden yazma süreci sonunda ortaya koydukları metni anlam bütünlüğü ve mantık akışı, yazım kuralları ve noktalama, başlık ile içerik uyumu açısından değerlendirmeleri beklenmektedir. Bu basamak aracılığıyla öğrenciler yazma sırasında yaptıkları hataları fark etme ve bu hataları düzeltme fırsatı bulacaklardır.

\section{Yöntem}

\section{Araştırmanın Modeli}

Sosyal bilim araştırmalarında değişkenler arasında nedensel ilişkileri test etmek için en güçlü yöntem deneysel araştırma desenleridir. Deneysel araştırmalar, araştırmacıya incelediği bağımsız değişkenlere müdahale ederek bağımlı değişken üzerindeki değişimleri kıyaslama imkânı verdiğinden, olgular arasında sebep-sonuç ilişkisi (nedensellik) yorumu daha kolay yapılabilmektedir (Gürbüz ve Şahin, 2016: 367).

Bu araştırmada öyküleyici metin türünde yazma becerisini geliştirmeye yönelik geliştirilmesi hedeflenen Kurgu Merdiveni'nin ortaokul öğrencilerinin yazma tutum ve başarısına etkisini belirlemek için deneysel araştırma yöntemlerinden ön test son test kontrol gruplu model kullanıımıştır.

\section{Örneklem / Araştırma grubu}

Araştırmanın çalışma grubu 2017- 2018 eğitim öğretim yılında Bursa ilinde bulunan bir ortaokulda öğrenim gören 44 yedinci sınıf öğrencisinden oluşmaktadır. Rastlantısal olarak belirlenen deney ve kontrol grubunda 20'şer öğrenci bulunmaktadır. Deney ve kontrol grubuna ait veriler Tablo 1'de gösterilmiştir.

Tablo 1. Deney Grubu ve Kontrol Grubuna Ait Veriler

\begin{tabular}{lcccc}
\hline \multirow{2}{*}{ Cinsiyet } & \multicolumn{2}{c}{ Deney Grubu } & \multicolumn{2}{c}{ Kontrol Grubu } \\
\cline { 2 - 5 } & $\mathrm{N}$ & $\%$ & $\mathrm{~N}$ & $\%$ \\
\hline Erkek & 9 & 45 & 11 & 55 \\
\hline KIz & 11 & 55 & 9 & 45 \\
\hline Toplam & 20 & 100,0 & 20 & 100,0 \\
\hline
\end{tabular}

Tablo 1'ye göre deney grubundaki öğrencilerin $\% 55^{\prime} i$ ( $\left.f=11\right) \quad k ı, \quad \% 45^{\prime} i$ ( $f=9$ ) erkek öğrencilerden oluşmaktadır. Kontrol grubundaki öğrencilerin ise $\% 45^{\prime} i(f=9)$ kı, $\% 55^{\prime} i(f=11)$ erkek öğrencilerden oluşmaktadır. Çalışma grubunu oluşturan öğrencilerin tamamında kız ve erkek öğrenci oranları (\%50) eşittir. Buna göre grupların cinsiyet faktörüne göre denk oldukları görülmektedir. 


\section{Veri Toplama Araçları}

Araştırmanın verileri Can ve Topçuoğlu Ünal'ın (2017) geliştirdiği “Ortaokul Öğrencilerine Yönelik Yazma Tutum Ölçeği" ve araştırmacı tarafından geliştirilen Öyküleyici Anlatım Değerlendirme Formu kullanılarak elde edilmiştir.

Araştırmada geliştirilmesi hedeflenen Kurgu Merdiveni uygulamasının öğrencilerin yazma tutumuna etkisini belirlemek için Ortaokul Öğrencilerine Yönelik Yazma Tutum Ölçeği (OÖYYTÖ) geliştirilmiştir. Can ve Topçuoğlu Ünal (2017) tarafından yapılan OÖYYTÖ’nün geçerlik ve güvenirlik çalışması sonucunda OÖYYTÖ’nün 23 maddeden oluşan üç boyutlu (ilgi, algı, katkı) bir ölçme aracı olduğu ortaya konmuştur.

Araştırmada geliştirilmesi hedeflenen Kurgu Merdiveni uygulamasının öyküleyici metin türünde yazma başarısına etkisini belirlemede kullanılmak üzere araştırmacı tarafından Öyküleyici Anlatım Değerlendirme Formu (ÖADF) geliştirilmiştir. Araştırmacı tarafından yapılan geçerlik ve güvenirlik çalışması sonucunda ÖADF, on ölçütten (sayfa düzeni, başıı, kişiler, mekan, zaman, kurgu, anlam bütünlüğü, yazı planı, yazım, noktalama) oluşmuştur.

\section{Verilerin Analizi}

Deney ve kontrol grubundan elde edilen verilerin analizi konusunda hangi testlerin uygulanacağını tespit etmek için verilerin dağılımı incelenmiştir. Bu inceleme sonunda deney ve kontrol grubu verilerinin normal dağılım göstermediği belirlenmiş, deney ve kontrol grubu ön test ve son testlerinin analizinde nonparametrik testlerden Mann Whitney U-Testi kullanılmıştır. Deney grubu ön test ve son testi arasındaki ilişki ve kontrol grubu ön test ve son testi arasındaki ilişki ise Bağımsız Örneklemler T-Testi ile incelenmiştir.

\section{Bulgular}

Deney grubu öğrencilerinin uygulama öncesi ve uygulama sonrasında yazdıkları metinlerden aldıkları toplam ortalama puanlar incelenmiştir. Deney grubunun ÖADF'ye göre ön test ve son testten aldığı toplam ortalama puanlar arasındaki fark incelenmek üzere Bağımsız Örneklemler T-Testi yapılmıştır. Deney grubu öğrencilerinin AÖDF'ye göre ön test ve son testten aldığı toplam ortalama puanlara ilişkin veriler Tablo 2'de gösterilmiştir.

Tablo 2. Ön test ve Son test Sonuçlarına Göre Deney Grubu Öğrencilerinin ÖADF'den Aldıkları Puanlara Ilişsin TTesti Sonucu

\begin{tabular}{lcccccc}
\hline & $\mathrm{N}$ & Ortalama & Std. Sapma & Sd & $\mathrm{t}$ & $\mathrm{p}$ \\
\hline Öntest & 20 & 1,81 &, 35821 & 38 & $-2,484$ &, 018 \\
Sontest & 20 & 2,19 &, 58300 & & & \\
\hline
\end{tabular}

Tablo 2'ye göre deney grubu öğrencilerinin ön test ve son testten aldıkları toplam ortalama puanlar arasında anlamlı bir fark bulunmaktadır $\left(t_{20}=-2,484 ; p<, 05\right)$. Buna göre son test puan ortalaması $(\bar{x}=2,19)$ ön test puan ortalamasından $(\bar{x}=1,81)$ yüksektir. Elde edilen bu bulgudan 
hareketle Kurgu Merdiveni kullanılarak deney grubunda verilen yazma eğitiminin öğrencilerin yazma başarısını arttırdığı söylenebilir. Buna bağlı olarak Kurgu Merdiveni'nin ortaokul öğrencilerinin yazma becerisini olumlu yönde etkilediği sonucu çıkarılabilir.

Kontrol grubu öğrencilerinin uygulama öncesi ve uygulama sonrasında yazdıkları metinlerden aldıkları toplam ortalama puanlar incelenmiştir. Kontrol grubunun ÖADF'ye göre ön test ve son testten aldığı toplam ortalama puanlar arasındaki fark incelenmek üzere Bağımsız Örneklemler TTesti yapılmıştır. Kontrol grubu öğrencilerinin AÖDF'ye göre ön test ve son testten aldığı toplam ortalama puanlara ilişkin veriler Tablo 3'te verilmişsir.

Tablo 3. Ön test ve Son test Sonuçlarına Göre Kontrol Grubu Öğrencilerinin ÖADF'den Aldıkları Ortalama Puanlara ilişkin T-Testi Sonucu

\begin{tabular}{lcccccc}
\hline & $\mathrm{N}$ & Ortalama & Std. Sapma & Sd & $\mathrm{t}$ & $\mathrm{p}$ \\
\hline Öntest & 20 & 1,80 &, 26754 & 38 & 1,123 &, 269 \\
Sontest & 20 & 1,66 &, 48925 & & & \\
\hline
\end{tabular}

Tablo 3'e göre kontrol grubu öğrencilerinin ön test ve son testten aldıkları toplam ortalama puanlar arasında anlamlı bir fark bulunmamaktadır $\left(t_{20}=1,123 ; p>, 05\right)$. Buna göre ön test puan ortalaması $(\bar{x}=1,80)$ son test puan ortalamasından $(\bar{x}=1,66)$ yüksektir. Ulaşılan bu sonuçlar, kontrol grubu öğrencilerinin uygulama öncesi ile uygulama sonrası yazma başarıları arasında bir farklılık olamadığını göstermektedir.

Deney ve kontrol grubu öğrencilerinin uygulama öncesi yazdıkları metinlerden aldıkları ön test puanları arasında fark olup olmadığı incelenmiştir. Bu kapsamda gruplar arası fark olup olmadığını belirlenmek için Mann Whitney U-Testi uygulanmıştır. Deney ve kontrol grubu öğrencilerinin ÖADF'ye göre ön testten aldıkları toplam ortalama puanlarına ait veriler Tablo 4'te gösterilmiştir.

Tablo 4. Ön test Sonuçlarına Göre Deney ve Kontrol Grubu Öğrencilerinin ÖADF'den Aldıkları Ortalama Puanlara Ait U-Testi Sonucu

\begin{tabular}{lccccc}
\hline Gruplar & N & Sira Ortalaması & Sira Toplamı & U & p \\
\hline Deney Grubu & 20 & 20,08 & 401,50 & 191,500 &, 817 \\
Kontrol Grubu & 20 & 20,93 & 418,50 & & \\
\hline
\end{tabular}

Tablo 4'e göre deney grubu öğrencileri ile kontrol grubu öğrencilerinin ön test toplam ortalama puanları anlamlı bir fark göstermemektedir $(U=191,500 ; p>, 05)$. Bu bulguya göre uygulama öncesinde deney grubu ve kontrol gurubu öğrencilerinin ÖADF'den aldıkları toplam ortalama puana göre yazma başarısı açısından eşit seviyede oldukları söylenebilir.

Deney ve kontrol grubu öğrencilerinin uygulama sonrası yazdıkları metinlerden aldıkları son test puanları arasında fark incelenmiştir. Bu kapsamda gruplar arası fark olup olmadığı incelenmek üzere Mann Whitney U-Testi yapılmıştır. Deney ve kontrol grubu öğrencilerinin ÖADF'ye göre son testten aldıkları toplam ortalama puanlarına ait veriler Tablo 5 'te verilmiştir. 
Öyküleyici Metin Türünde Yazma Becerisini Geliştirmeye Yönelik Bir Uygulama: Kurgu Merdiveni

Tablo 5. Son test Sonuçlarına Göre Deney ve Kontrol Grubu Öğrencilerinin ÖADF'den Aldıkları Ortalama Puanlara Ait U- Testi Sonucu

\begin{tabular}{lccccc}
\hline Gruplar & N & Sıra Ortalaması & Sıra Toplamı & U & $p$ \\
\hline Deney Grubu & 20 & 25,48 & 509,50 & 100,500 &, 007 \\
Kontrol Grubu & 20 & 15,53 & 310,50 & & \\
\hline
\end{tabular}

Tablo 5'e göre deney grubu öğrencileri ile kontrol grubu öğrencilerinin son test toplam ortalama puanları deney grubu lehine anlamlı bir fark göstermektedir $(U=100,500 ; p<, 05)$. Bu bulguya göre Kurgu Merdiveni kullanılarak deney grubunda verilen yazma eğitiminin yazma başarısını olumlu yönde etkilediği söylenebilir. Buna bağlı olarak Kurgu Merdiveni'nin ortaokul öğrencilerinin yazma becerisini geliştirdiği anlaşılmaktadır.

Deney grubu öğrencilerinin OÖYYTÖ’ye göre ön test ve son testten aldığı toplam ortalama puanlar arasında fark incelenmiştir. Bu kapsamda ön test ve son test toplam ortalama puanları arasındaki fark incelenmek üzere Bağımsız Örneklemler T-Testi yapılmıştır. Deney grubu öğrencilerinin OÖYYTÖ’ye göre ön test ve son testten aldığı toplam ortalama puanlara ait veriler Tablo 6'da verilmiştir.

Tablo 6. Ön test ve Son test Sonuçlarına Göre Deney Grubu Öğrencilerinin OÖYYTÖ'den Aldıkları Toplam Ortalama Puanlarına Ait T-Testi Sonucu

\begin{tabular}{lllllll} 
& $\mathrm{N}$ & Ortalama & Std. Sapma & $\mathrm{Sd}$ & $\mathrm{t}$ & $\mathrm{p}$ \\
\hline Öntest & 20 & 3,6391 &, 58078 & 38 & $-2,145$ &, 038 \\
Sontest & 20 & 3,9674 &, 36236 & & & \\
\hline
\end{tabular}

Tablo 6'ya göre deney grubu öğrencilerinin ön test ve son test toplam ortalama puanları arasında anlamlı bir fark bulunmaktadır $\left(\mathrm{t}_{20}=-2,145 ; \mathrm{p}<, 05\right)$. Bu bulguya göre Kurgu Merdiveni kullanılarak deney grubunda verilen yazma eğitiminin yazmaya yönelik tutumu olumlu yönde etkilediği belirlenmiştir.

Elde edilen bu bulgudan hareketle Kurgu Merdiveni'nin, ortaokul öğrencilerinin yazmaya yönelik tutumlarını olumlu yönde geliştirdiği anlaşılmaktadır.

Kontrol grubu öğrencilerinin OÖYYTÖ’ye göre ön test ve son testten aldığı toplam ortalama puanlar arasında fark incelenmiştir. Bu kapsamda ön test ve son test toplam ortalama puanları arasındaki fark incelenmek üzere Bağımsız Örneklemler T-Testi yapılmıştır. Kontrol grubu öğrencilerinin OÖYYTÖ’ye göre ön test ve son testten aldığı toplam ortalama puanlara ait veriler Tablo 7'de verilmiştir.

Tablo 7. Ön test ve Son test Sonuçlarına Göre Kontrol Grubu Öğrencilerinin OÖYYTÖ'den Aldıkları Ortalama Puanlarına Ait T-Testi Sonucu

\begin{tabular}{lcccccc}
\hline & $\mathrm{N}$ & Ortalama & Std. Sapma & Sd & $\mathrm{t}$ & $\mathrm{p}$ \\
\hline Öntest & 20 & 3,5348 &, 53420 & 38 &,- 204 &, 839 \\
Sontest & 20 & 3,5761 &, 72943 & & & \\
\hline
\end{tabular}

Tablo 7’ye göre kontrol grubu öğrencilerinin ön test ve son test toplam ortalama puanları arasında anlamlı bir fark bulunmamaktadır $\left(t_{20}=-, 204 ; p>, 05\right)$. Bu bulguya göre kontrol grubu 
öğrencilerinin uygulama öncesi ile uygulama sonrasında yazmaya yönelik tutumlarında bir farklılık görülmemektedir.

Deney grubu ile kontrol grubu öğrencilerinin OÖYYTÖ'ye göre ön testten aldıkları toplam ortalama puanları arasında fark incelenmiştir. Bu kapsamda gruplar arası fark incelenmek üzere illişkisiz Örneklemler T-Testi yapılmıştır. Deney ve kontrol grubu öğrencilerinin OÖYYTÖ’ye göre ön testten aldıkları toplam ortalama puanlarına ait veriler Tablo 8'de gösterilmiştir.

Tablo 8. Ön test Sonuçlarına Göre Deney ve Kontrol Grubu Öğrencilerinin OÖYYTÖ'den Aldıkları Ortalama Puanlarına Ait T-Testi Sonucu

\begin{tabular}{lcccccc}
\hline Gruplar & $\mathrm{N}$ & Ortalama & Std. Sapma & Sd & $\mathrm{t}$ & $\mathrm{p}$ \\
\hline Deney Grubu & 20 & 3,6391 &, 58078 & 38 &, 591 &, 558 \\
Kontrol Grubu & 20 & 3,5348 &, 53420 & & & \\
\hline
\end{tabular}

Tablo 8'e göre deney ve kontrol grubu öğrencilerinin ön testten aldıkları toplam ortalama puanlar arasında anlamlı bir fark bulunmamaktadır $\left(t_{40}=, 591 ; p>, 05\right)$. Bu bulgudan hareketler deney grubu öğrencileri ile kontrol grubu öğrencilerinin uygulama öncesinde yazmaya yönelik tutum açısından denk oldukları söylenebilir.

Deney grubu ile kontrol grubu öğrencilerinin OÖYYTÖ'ye göre son testten aldıkları toplam ortalama puanları arasındaki fark incelenmiştir. Bu kapsamda gruplar arası fark incelenmek üzere Bağımsız Örneklemler T-Testi yapılmıştır. Deney ve kontrol grubu öğrencilerinin OÖYYTÖ’ye göre son testten aldıkları toplam ortalama puanlarına ait veriler Tablo 9'da gösterilmiştir.

Tablo 1. Son test Sonuçlarına Göre Deney ve Kontrol Grubu Öğrencilerinin OÖYYTÖ'den Aldıkları Ortalama Puanlarına Ait T-Testi sonucu

\begin{tabular}{lcccccc}
\hline Gruplar & $\mathrm{N}$ & Ortalama & Std. Sapma & Sd & $\mathrm{t}$ & $\mathrm{p}$ \\
\hline Deney Grubu & 20 & 3,9674 &, 36236 & 38 & 2,149 &, 038 \\
Kontrol Grubu & 20 & 3,5761 &, 72943 & & & \\
\hline
\end{tabular}

Tablo 9'a göre deney ve kontrol grubu öğrencilerinin son testten aldıkları toplam ortalama puanlar arasında deney grubu lehine anlamlı bir fark bulunmaktadır $\left(t_{40}=2,149 ; p<, 05\right)$. Bu bulguya göre deney grubu öğrencilerinin OÖYYTÖ’ye göre son test puan ortalaması $(\bar{x}=3,9674)$, kontrol grubu son test puan ortalamasından $(\bar{x}=3,5761)$ yüksektir.

Elde edilen bu sonuca göre deney grubunda Kurgu Merdiveni kullanılarak verilen yazma eğitimi, öğrencilerin yazmaya yönelik tutumlarını olumlu yönde etkilemiştir. Bu bağlamda Kurgu Merdiveni'nin ortaokul öğrencilerinin yazmaya yönelik tutumlarını olumlu yönde geliştirdiği anlaşılmaktadır.

Yukarıda elde edilen bulgularda görüldüğü üzere Kurgu Merdiveni, öyküleyici metin türünde ortaokul öğrencilerinin yazma başarılarını arttırmalarına katkı sağlamış ve yazmaya yönelik tutumlarını olumlu yönde etkilemiştir. 


\section{Tartışma, Sonuç ve Öneriler}

Birey açısından önemi her geçen gün biraz daha artan, iletişim yollarından biri olan yazmanın ilköğretim sıralarında bir beceri olarak geliştirilmesi önemlidir. Özellikle ortaokul kademesinde yazma becerisinin geliştirilebilmesi, yazmanın bir alışkanlık haline getirilebilmesi öğrencilere yazmayı sevdirmekle, öğrencilerin yazmaya karşı ilgi duymalarını sağlamakla mümkündür. Bunun için Türkçe öğretmenlerine önemli derecede iş düşmektedir.

Öğrencilere yazmayı sevdirebilmek için yazmayı eğlenceli hale getirmek gerekir. Öğrencilere yazabilme hazzını yaşatmak önemlidir. Bu açıdan öğretmenin yazma eğitimi kapsamında derste uygulayacağı ve öğrencilere uygulatacağı yöntem, teknik ve uygulamalar etkili olacaktır. Öğretmenin ders içerinde kullanacağı uygulamalar öncelikle hedef öğrenci seviyesine uygun olmalı, sadece öğretmen tarafından değil, öğrenciler tarafından da rahatlıkla anlaşılabilir ve uygulanabilir olmalıdır. Bununla birlikte tercih edilecek uygulamalar ilgi çekici olmalı, öğretici olmasının yanında eğlendirici olmalıdır.

Alanyazın tarandığında bu araştırmaya benzer bir çalışma olarak Sidekli'nin (2012) "Yazma Becerisini Geliştirmek İçin Hikâye Piramidi" adlı çalışması görülmektedir. Sidekli (2012) bu çalışmasında, Hikâye Piramidi'nin sınıf öğretmeni adayı birinci sınıf öğrencilerinin hikâye yazma becerilerine etkisini incelemiştir. Araştırmada yöntem olarak eylem araştırması yöntemi kullanılmıştır. Araştırmanın sonunda hikâyede başlık, kahraman, yardımcı kahraman, mekân, zaman, konu, ana fikir, giriş, gelişme, sonuç bölümü bulunması konusunda Hikâye Piramidi'nin olumlu katkı sağladığı belirlenmiştir.

Bu araştırmada ise Kurgu Merdiveni'nin ortaokul öğrencilerinin öyküleyici anlatım biçiminde yazma başarısına ve yazmaya yönelik tutumlarına etkisi incelenmiştir. Araştırmada yöntem olarak ön test son test kontrol gruplu deneysel model kullanılmıştır. Bu iki araştırma kullanılan yöntem ve çalışma grupları açısından farklılık göstermektedir. Araştırmanın sonunda Kurgu Merdiveni'nin ortaokul öğrencilerinin öyküleyici anlatım biçiminde yazma başarısına katkı sağladığı ve yazmaya yönelik tutumlarını olumlu yönde etkilediği tespit edilmiştir.

Yazma becerisini geliştirmeye yönelik uygulamaları konu edinen diğer bir araştırma da Tağa'nın (2013) “ilköğğretim 7. Sınıf Türkçe Dersinde Kullanılan Zihin Haritası Tekniğinin Öğrencilerin Yazma Becerilerine Etkisi” adlı araştırmasıdır. Tağa (2013), bu araştırmasında zihin haritası tekniğinin öğrencilerin yazma becerilerine etkisini incelemiş ve öğrencilerin zihin haritası tekniği ile yapılan yazma çalışmalarına ilişkin olumlu bir görüşe sahip olduğunu, zihin haritası tekniğinin yazma becerilerini -biçim, dil ve anlatım, imlâ ve noktalama yönünden- geliştirmede programda yer alan yazma tekniklerinden daha etkili olduğunu tespit etmiştir.

Bu araştırmada ise Kurgu Merdiveni'nin ortaokul öğrencilerinin yazma başarısını ve yazmaya yönelik tutumlarını olumlu yönde etkilediği tespit edilmiş, yazma başarısı açısından Kurgu 
Merdiveni'nin yazma becerisine "sayfa düzeni, başlık, kişiler, mekân, kurgu, anlam bütünlüğü" yönünden katkı sağladığı belirlenmiştir.

Anılan (2005) yaptığı araştırmasında kelime ağı oluşturma yönteminin, öğrencilerin yazıı anlatım becerilerinin gelişimine etkisini incelemiştir. Bu amaç doğrultusunda Türkçe dersi yazılı anlatım çalışmalarının kelime ağı oluşturma yöntemine göre gerçekleştirilebilmesi için ders planları ve materyalleri geliştirmiştir. Araştırmanın sonunda kelime ağı oluşturma yönteminin uygulandığı deney grubunda, kontrol grubuna göre istatistiksel bakımdan anlamlı bir fark bulunmuştur.

Bu araştırmada ise Kurgu Merdiveni'nin ortaokul 7. sınıf öğrencilerinin öyküleyici anlatım biçiminde yazma başarısına ve yazma tutumlarına etkisi incelenmiştir. Araştırmanın sonunda Kurgu Merdiveni uygulamasının ortaokul 7. sınıf öğrencilerinin öyküleyici anlatım biçiminde yazma başarılarına katkı sağladığı ve yazmaya yönelik tutumlarını olumlu yönde etkilediği tespit edilmiştir.

Araştırma sonucunda elde edilen bulgulara dayalı olarak ulaşılan sonuçlar şöyledir:

Kurgu Merdiveni uygulamasının ortaokul öğrencilerinin yazma başarısına etkisi konusunda yapılan incelemeler sonucunda Kurgu Merdiveni uygulamasının öğrencilerin yazma başarısını arttırdığı tespit edilmiş̧ir. Kurgu Merdiveni kullanılarak deney grubunda uygulanan yazma eğitiminin öğrencilerin yazma başarısına katkı sağladığı belirlenmiştir. Buna bağlı olarak Kurgu Merdiveni'nin ortaokul öğrencilerinin yazma becerisini olumlu yönde etkilediği sonucuna ulaşılmıştır.

Kurgu Merdiveni uygulamasının ortaokul öğrencilerinin yazmaya yönelik tutumlarına etkisi konusunda yapılan incelemeler sonucunda Kurgu Merdiveni uygulamasının öğrencilerin yazmaya yönelik tutumlarını olumlu yönde etkilediği tespit edilmiştir. Kurgu Merdiveni kullanılarak deney grubunda uygulanan yazma eğitiminin öğrencilerin yazmaya yönelik tutumlarında olumlu yönde bir değişim sağladığı belirlenmiştir. Buna bağlı olarak Kurgu Merdiveni'nin, ortaokul öğrencilerinin yazmaya yönelik tutumlarını olumlu yönde geliştirdiği anlaşılmıştır.

Araştırmanın genel sonucu olarak Kurgu Merdiveni uygulamasının öyküleyici metin türünde ortaokul öğrencilerinin yazma başarılarını arttırmalarına katkı sağladığı ve yazmaya yönelik tutumlarını olumlu yönde etkilediği sonucuna ulaşılmıştır.

Araştırmada ulaşılan sonuçlardan hareketle şu öneriler geliştirilebilir:

- Kurgu Merdiveni, Türkçe öğretmenleri tarafından öğrencilerin yazma becerisini geliştirmek amacıyla kullanılabilir.

- Kurgu Merdiveni, Türkçe öğretmenleri tarafından öğrencilerin yazmaya yönelik tutumlarını olumlu yönde geliştirmek amacıyla kullanılabilir.

- Kurgu Merdiveni, Türkçe öğretmenlerinin öğrencilerin dikkatini derse çekmelerinde, derse yönelik öğrencilerin motivasyonunu arttırmalarında, dersi ilgi çekici ve eğlenceli hale getirmelerinde yardımcı olacaktır. 
- Kurgu Merdiveni, öğrencilerin öğretmenlerinden destek almadan kendi kendilerine kullanabilecekleri bir tekniktir. Bu açıdan Kurgu Merdiveni Tekniği öğrencilerin okul dışında yazma alışkanlığı kazanmaları noktasında faydalı olacaktır.

\section{Kaynaklar}

Anılan, H. (2005). Yazılı anlatım becerilerinin geliştirilmesinde kelime ağı oluşturma yönteminin etkililiği. (Doktora Tezi). Anadolu Üniversitesi Eğitim Bilimleri Enstitüsü, Eskişehir.

Can, E. ve Ünal, F. T. (2017). Ortaokul öğrencilerine yönelik yazma tutum ölçeği: geçerlik ve güvenirlik çalışması. International Journal of Languages' Education and Teaching, 5(3), 203-212.

Göçer, A. (2016). Yazma uğraşı yazma eğitimi. Ankara: Pegem Akademi.

Graham, S., Berninger, V. \& Fan, W. (2007). The structural relationship between writing attitude and writing achievement in first and third grade students. Contemporary Educational Psychology, (32), 516-536.

Gürbüz, S. ve Şahin, F. (2016). Sosyal bilimlerde araştırma yöntemleri felsefe- analiz- yöntem. Ankara: Seçkin Yayınları.

Karadağ, Ö. ve Maden, S. (2014). Yazma eğitimi: kuram, uygulama, ölçme ve değerlendirme. İçinde A. Güzel ve H. Karatay (Ed.) Türkçe öğretimi el kitabı (s. 265-301). Ankara: Pegem Akademi.

Karatay, H. (2011). 4+1 Planlı yazma ve değerlendirme modelinin öğretmen adaylarının yazılı anlatım tutumlarını ve yazma becerilerini geliştirmeye etkisi. Turkish Studies, 6(3), 1029-1047.

Sidekli, S. (2012). Yazma becerisini geliştirmek için hikâye piramidi. Akademik Bakış Dergisi, 31, 1-18.

Tağa, T. (2013). Illköğretim 7. sınıf Türkçe dersinde kullanılan zihin haritası tekniğinin öğrencilerin yazma becerisine etkisi. (Yüksek Lisans Tezi). Necmettin Erbakan Üniversitesi Eğitim Bilimleri Enstitüsü, Konya.

Temizkan, M. (2010). Türkçe öğretiminde yaratıcı yazma becerilerinin geliştirilmesi. TÜBAR, XXVII, 621-643.

Ungan, S. (2007). Yazma becerisinin geliştirilmesi ve önemi. Sosyal Bilimler Enstitüsü Dergisi, 23, 461- 472.

Yaman, E. (2013). Yazma sanatı yazılı anlatım. Ankara: Akçağ Yayınları.

\section{Extended Abstract \\ Introduction}

Writing is to put down somebody's feelings, opinions, dreams, plans, lives on a paper (Göçer, 2016:27). According to Karadağ and Maden (2014:266) writing is to decipher the meaning wishing to be interpreted by the symbols called letters. Additionally, according to Karatay (2011), writing is the work of transferring feelings and opinions to others by using characters, symbols and marks which are utilized in any language. As mentioned in the definitions above, writing is a main tool that enables people to transfer their feelings, opinions, dreams and wishes. As a necessity of social life, persons should be able to express themselves in a healthy way in order to continue their lives in a society to which they belong. This is necessary for the person's communication with his/her environment. One of the efficient ways which will help a person express him/herself is writing. In this respect, writing is a personal need.

Given this information, the writing skill is necessary for a person to live happily and vigorously as socially and psychologically. In addition to having this skill, it is highly important to develop this skill. Writing is a skill that should be improved since it helps form healthy societies, because it affects person's social and psychological development, supplements his personal development and leads healthy communication among individuals. Thus, writing instruction which is given to students is of immense importance.

Firstly, students should feel motivated for writing to improve their writing skills. For students, to feel up to writing and to develop positive attitude for writing are closely related to the writing instruction applied. Especially in education process, it's vital for teachers to use different methods, technics and applications which engage students' interests and lead students like writing.

Not only different method, technics and implementations that teachers use in writing instruction will take the students' attentions, but also will promote students to acquire writing skills and improve them. Moreover, it can be possible to reverse students' negative opinions and attitudes into positive through the implementations which teachers will use in writing activities. In this context, it is needed to have methods, 
technics and implementations that can be used in writing instruction, can be made the writing process requiring the usage of many skills easy for students and will make them liked writing. In this research, a new implementation which can be used in writing instruction was tried to be improved by analysing the writing success of Fiction Stairs and its effect to attitude towards writing.

\section{Method}

In this research, pre-test and post-test control group model that are from research technics were used to decide the effects of Fiction Stairs which aims to improve writing skills of middle school students.

The data of the research were obtained by using "Writing Attitude Scale Towards Secondary School Students" that Can and Topçuoğlu Ünal (2017) formed and Narrative Evaluation Form formed by the researcher.

\section{Result and Discussion}

It's important to develop writing which becomes important for a person day by day and which is one of the ways of communication as a skill in primary education. Especially in the middle school, to be able to improve the writing skill and have the habit of writing are possible by making the students loved writing and providing to interest them in writing.

In order to make the students love writing, we should present writing as a fun activity. It is important for the students to experience the pleasure of writing. Thus, the methods, technics and implementations which teachers will use in the class for writing instruction will be efficient. The implementations the teacher will use in the class should be appropriate for the level of target students, firstly and should be comprehensible enough and applicable not only for the teachers, but also for the students. Moreover, the implementations that will be preferred should be interesting, educational and funny.

At the end of the research, it was found out that using Fiction Stairs for the $7^{\text {th }}$ grade students increased the writing success in narrative type and affected their attitudes toward writing positively. 
Ek

\section{KONTROL ET}

Anlam bütünlüğü ve mantık akışı yönünden metin incelenir.

$>$ Yazım kuralları ve noktalama bakımından metin incelenir.

$>$ Başı̆̆ın içeriğe uygunluğu incelenir.

\section{YAZ}

Kâğıt ve sayfa düzenine dikkat edilir.

$>$ "HAYAL ET" basamağında tasarlanalar genişletilerek yazıya dökülür.

$>$ Söz sanatlarından yararlanılır. (Betimleme, Kişileştirme, benzetme...)

$>$ Imla ve noktalamava dikkat edilir.

\section{HAREKETE GEÇ}

$>$ Metnin planı oluşturulur.

$>$ Anahtar kelimeler belirlenir.

$>$ Kelime havuzu oluşturulur.

$>$ Başık belirlenir.

\section{HAYAL ET}

Şahıs ve varlıkların fiziki ve psikolojik özellikleri düşünülür.

$>$ Yer(mekân) tanımlanarak zihinsel tasviri yapılır.

$>$ Zamanın özellikleri ve kahramanlar üzerindeki etkisi düşünülür.

$>$ Metinde yer verilecek olaylara kahramanların gözüyle bakılarak yazılacaklar zihinde tasarlanır.

\section{KARAR VER}

Metin türüne karar verilir.

Konu belirlenir.

Olay örgüsü belirlenir.

$>$ Şahıs ve varlık kadrosu oluşturulur.

$>$ Yer (mekân) seçimi yapilır.

$>$ Zaman belirlenir.

\section{DÜşüN}

Metin türleri ve özellikleri hatırlanır.

$>$ Yazmaya başlamadan önce bilgi toplanır. 